Conference Paper

\title{
Designing Business Process Improvement that Concentrates on IT Utilization at LPPM UPN “Veteran” Jawa Timur
}

\author{
Mohamad Irwan Afandi *, Eka Dyar Wahyuni \\ Information System Department, Faculty of Computer Science, Universitas Pembangunan Nasional \\ "Veteran" Jawa Timur, Indonesia
}

*Corresponding author:

E-mail:

mohamadafandi.si@upnjatim.ac.id

\begin{abstract}
To enhance operational efficiency, several organizations have pursued business process re-engineering initiatives. Inevitably, this initiative involves the modernization and modification of existing information systems to support business processes. UPN "Veteran" Jawa Timur is no exception; as a higher education institution carrying out its tri-dharma mission, UPN needs to improve its efficiency continuously. Lembaga Penelitian dan Pengabdian Masyarakat (LPPM) manages two of UPN "Veteran" Jawa Timur's tri-dharma related to research and community service. LPPM UPN Veteran itself is classified in an "independent" cluster so that independent research grants can be handled internally. This LPPM oversees the processes of administration and the execution of analysis and community service. There are many obstacles to implementing these processes at this time, such as data that is not recorded in a good structure, making it challenging when information is immediately required. And the most critical thing is that these data are still not integrated with performance data for lecturers. Therefore, this research aims to solve these problems by reviewing existing business processes and developing new business processes to improve current business processes. The result of this research is a list of functional and non-functional requirements of applications that will be developed.
\end{abstract}

Keywords: Business process management, business process reengineering, business process improvement, applications.

\section{Introduction}

Nowadays, it is quite common for organizations to use the support of computer-based applications/information systems in carrying out their various business processes. With this application, they get multiple kinds of convenience; the main thing is that automation and operates without space and time limitation capability. These organizations then undertake business process re-engineering initiatives to improve organizational performance. This initiative inevitably involves redesign and changes to existing information systems that support business processes.

The same thing happened at UPN "Veteran" Jawa Timur. UPN "Veteran" Jawa Timur, as a higher education institution that carries out Tri Dharma duties, also needs to make efforts to continue to improve the performance of the organization, especially in the field of research and community service. This effort includes the business process of 1) administering research grants and community service grants funded internally by UPN "Veteran" Jawa Timur in one full cycle. 2) The management of research results, starting from making prototypes/research results until downstream of the research results. 3) The management of scientific publications, and also 4) the management of research-based business development. At this time, the business process of carrying out the above activities still experiences many obstacles such as data that is not recorded in a good structure, making it complicated when there is a 
need for detailed/summary information (within a certain period) that need to be fulfilled in a fast time and/or information that is not recorded in a good structure.

Implications for information systems and how an organization's existing systems can evolve to support re-engineering projects (to improve organizational performance) is a relatively under-researched area. This study discusses how to redesign an information system that is integrated with the business process re-engineering through a review of relevant literature and empirical research (Weerakkody et al., 2003). Various methodologies are available for process improvement. These include BPI framework, Six Sigma, 3 Lean Management, Lean Six Sigma, Agile Management, Reengineering, Total Quality Management, Timely, Kaizen, Hoshin Planning, Poka-Yoke, Experimental Design, and Process Advantage. All consulting firms seem to have one that they claim is the best. All approaches claim to be the best way to achieve a similar goal, leaving any organization confused about deciding which one is best for them. In this research, the methodology used is the Business Process Improvement (BPI) method. Business Process Improvement is a systematic system framework that assists an organization in advancing or improving business processes. BPI's main objective is to improve business processes and ensure that issues in an organization's business processes are appropriately addressed (Harrington, 1991b).

This study aims to solve the problems of LPPM as described in the previous paragraph by reviewing the existing business processes and developing new business processes that can improve current business processes as has been applied in (Bhakti \& Herliani, 2018; Helmi et al., 2018). The result of this research is a list of functional and non-functional requirements of applications that will be developed.

\section{Material and Methods}

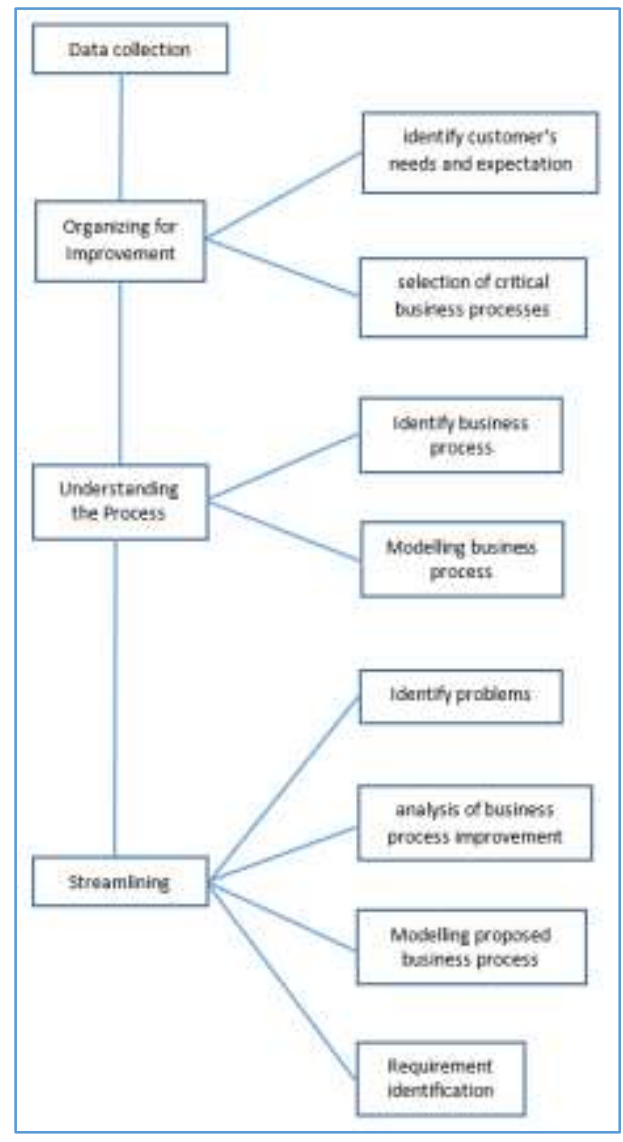

Figure 1. Research methodology 
The first step starts with data collection by checking related documentation, such as guides for the lecturer to create a research proposal, assessment forms used in proposal review stages, etc. Next, identify customer's needs and expectations and selection of critical businesss processes. After that, identify the business process (stages, process) and model it using BPMN. The next step is to identify problems in current business processes, analyze business process improvement, and modeling the proposed business process using BPMN. The final step is defining the requirement for the application.

\section{Results and Discussion}

\section{Organizing for Improvement}

Of the four business processes described above, this study will discuss the business process of administering research grants and community service grants funded-internally because this is the primary business process of LPPM, and most LPPM's performance indicators are in this area. The next step is to identify the related business process. Every unit in UPN "Veteran" Jawa Timur has KPI that is stated in an application called SIKOJA, which displays the unit's indicator, unit's targets, and unit's performance. This KPI will be evaluated periodically. KPI derived from "Sikoja" is used and then mapped into the main business processes of LPPM that are already mentioned above (administering research and community service grant funded-internally), as shown in table 1.

Table 1. Mapping performance indicator to Administering research and community service grant fundedinternally business process

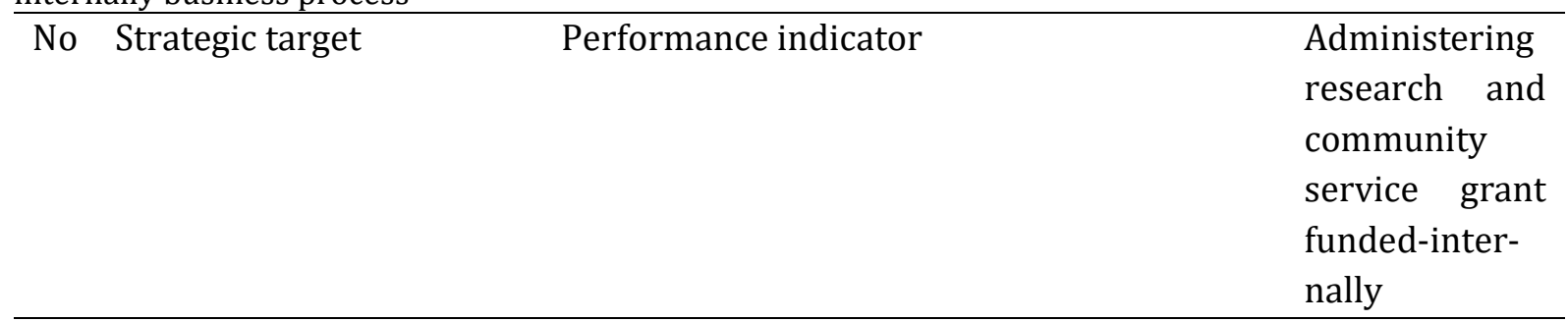

1 Increasing Quality of Stu- 1 . The number of entrepreneurial students dent Learning and Higher Education

2 Increased relevance and productivity of research and development

1. The number of foreign researchers

2. The number of international publications

3. The number of registered intellectual $\sqrt{ }$ property

4. The number of citations of scientific pa- $\sqrt{ }$ pers

5. The number of reputable journals nationally indexed (SINTA)

6 . The number of reputable journals indexed globally

7. The number of research and development $\quad \sqrt{ }$ prototypes (research and development)

8. The number of industrial prototypes

9. The number of product innovations

3 Strengthening Capacity

1. The number of independent research (In$\sqrt{ }$ $\sqrt{2}$ and Results of Research ternal Funds)

2. The number of research on (External Funds) 


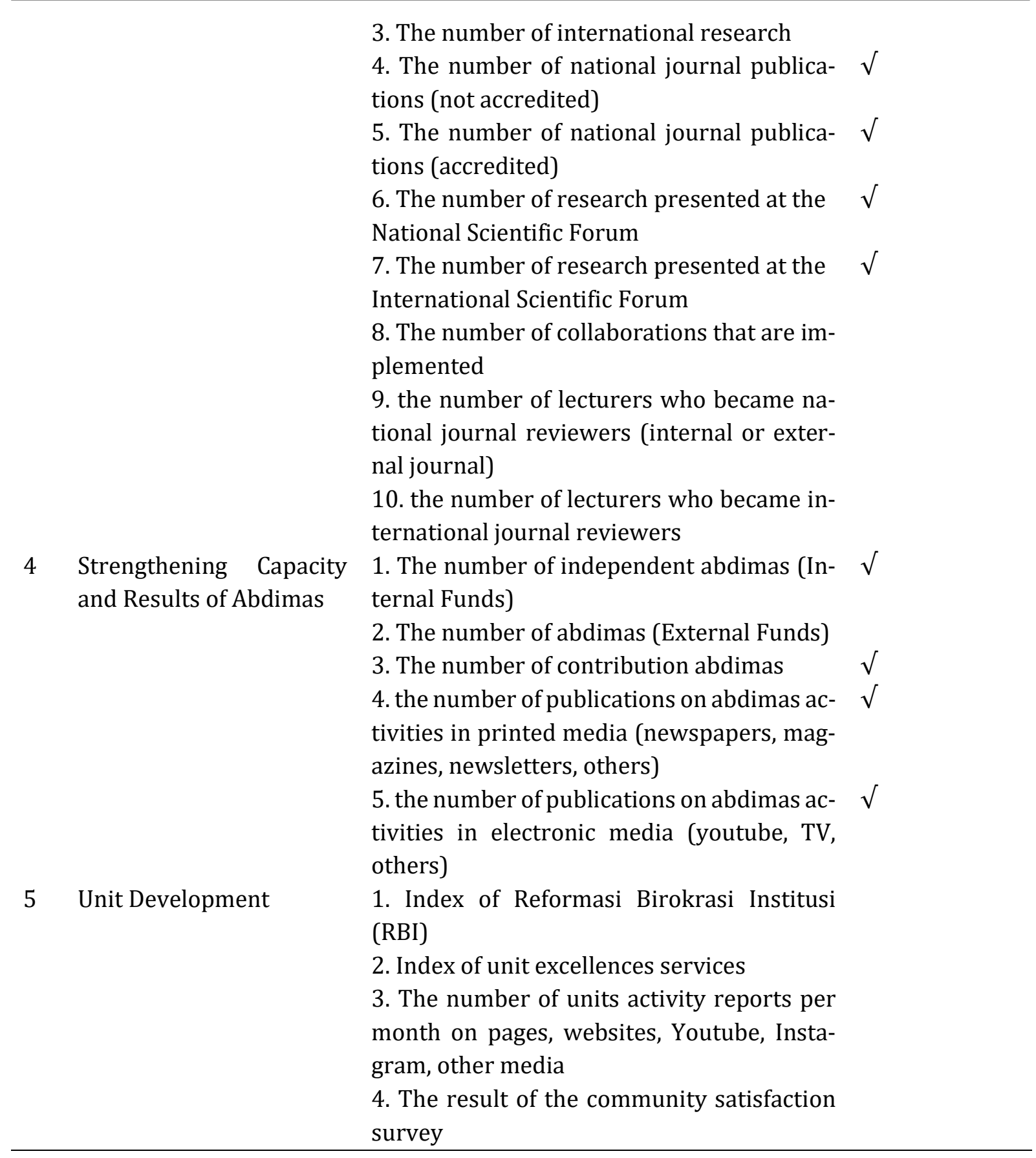

Of the 29 performance indicators, 15 indicators can be covered partially or entirely in the administering research and community service grant funded-internally business process.

\section{Understanding the process}

After 15 indicators are mapped into processes that occur during the administering research and community service grant funded-internally business process, three processes are obtained: 1 . proposal's upload and funded proposal's announcement; 2. LITDIMAS execution; 3. final report's upload and presentation. The next step is to explore and identify the business process. Business process components that will be identified include objectives, business process steps, technical environment, required inputs, and the resulting output. Business processes then modeled using the bizagi modeler application. An example of one flow is as shown in figure 2 . 


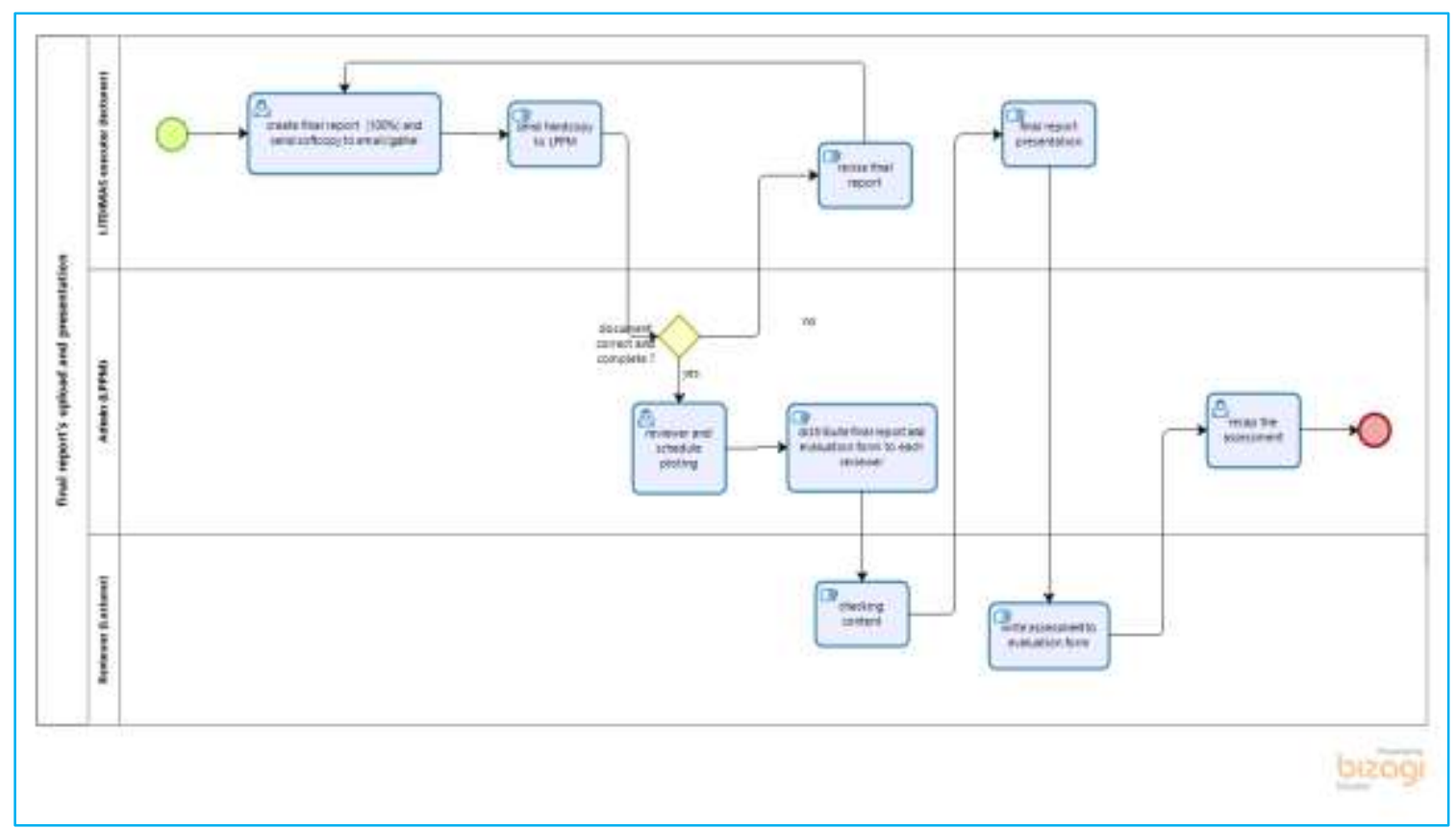

Figure 2. BPM of upload and presentation of the final report

There are two types of tasks used to model this process: manual tasks and user tasks. A manual task is a task that is expected to be performed without the aid of any business process execution or application. The manual task is symbolized with a hand icon in its process box. Some examples of manual tasks from figure 2 are: (1) send a hardcopy to LPPM and (2) distributing the final report and evaluation form to each reviewer. While user task is a typical workflow task where a person performs the task with the assistance of a software application; like (1) send a softcopy to email/google drive, this activity is carried out with the help of email or google drive, and (2) reviewer and schedule plotting assisted by MS Excel or MS Word.

\section{Streamlining}

The identified business processes have several problems. For each problem in a business process, this study tries to provide recommendations for improving the business process. The method that will be used for improvement is Process Business Improvement (BPI). There are 12 streaming tools at BPI (Harrington, 1991a), which are (1) Bureaucracy elimination; (2) Duplication elimination; (3) Value-added assessment; (4) Simplification; (5) Process cycle-time reduction; (6) Prevention of errors (Error proofing); (7) Improving performance; (8) Simplifying language; (9) Standardization; (10) Improving the quality of input; (11) Large scale improvements (Big picture improvement); and (12) Automation and/or mechanization. Of the 12 methods, not all tools are used to improve business processes. This study accustomed the improvement by looking at existing problems that can be solved using applications/information systems. Of the 12 methods above, the method chosen is processed cycle-time reduction, error proofing, and automation and/or mechanization. This problem mapping can be seen in table 2 . 
Table 2. Mapping of problem to improvement technique

\begin{tabular}{|c|c|c|c|c|}
\hline \multicolumn{5}{|c|}{ Business Process of Upload and Presentation of The Final Report } \\
\hline No & Problem & Risk & $\begin{array}{l}\text { Improvement } \\
\text { technique }\end{array}$ & Explanation \\
\hline 1 & $\begin{array}{l}\text { The recap process of } \\
\text { the softcopy final } \\
\text { report that has been } \\
\text { received by LPPM is } \\
\text { still done manually. } \\
\text { (from the process } \\
\text { "create the final re- } \\
\text { port (100\%) and } \\
\text { send softcopy to } \\
\text { email/google } \\
\text { drive") }\end{array}$ & $\begin{array}{l}\text { - It takes a long } \\
\text { time because it } \\
\text { still has to be } \\
\text { downloaded } \\
\text { one by one from } \\
\text { email/google } \\
\text { drive. } \\
\text { - prone to } \\
\text { missing data } \\
\text { because the } \\
\text { download } \\
\text { process still } \\
\text { clicks one by } \\
\text { one }\end{array}$ & $\begin{array}{l}\text { - } \text { process cycle- } \\
\text { time reduction } \\
\text { - error proofing } \\
\text { - } \text { automation }\end{array}$ & $\begin{array}{l}\text { Develop an information } \\
\text { system to support } \\
\text { business } \\
\text { activities (can display } \\
\text { all data - all final re- } \\
\text { port) }\end{array}$ \\
\hline 2 & $\begin{array}{l}\text { The distribution of } \\
\text { the schedule (for fi- } \\
\text { nal presentation) is } \\
\text { still done manually } \\
\text { through each } \\
\text { proposer's } \\
\text { WhatsApp number. } \\
\text { (from the process } \\
\text { "reviewer and } \\
\text { schedule plotting") }\end{array}$ & $\begin{array}{l}\text { - Sending the } \\
\text { wrong file } \\
\text { - There could be } \\
\text { a proposer that } \\
\text { did not receive } \\
\text { a schedule }\end{array}$ & $\begin{array}{ll}\text { - } & \text { process cycle- } \\
& \text { time reduction } \\
\text { - } & \text { error proofing } \\
\text { - } & \text { automation }\end{array}$ & \begin{tabular}{lr}
\multicolumn{2}{l}{ Develop an information } \\
system to & support \\
business & process \\
activities & (can display \\
each & presentation \\
schedule) &
\end{tabular} \\
\hline 3 & $\begin{array}{l}\text { The final report and } \\
\text { assessment form } \\
\text { are still paper- } \\
\text { based that distrib- } \\
\text { uted manually } \\
\text { (from the process } \\
\text { "distribute final re- } \\
\text { port and evaluation } \\
\text { form to each re- } \\
\text { viewer") }\end{array}$ & $\begin{array}{l}\text { - prone to lose } \\
\text { (missing docu- } \\
\text { ments) }\end{array}$ & $\begin{array}{ll}\text { - } & \text { process cycle- } \\
& \text { time reduction } \\
\text { - } & \text { error proofing } \\
\text { - } & \text { automation }\end{array}$ & $\begin{array}{l}\text { Develop an information } \\
\text { system to support } \\
\text { business process } \\
\text { activities (can plot re- } \\
\text { viewer to each pro- } \\
\text { poser and input the } \\
\text { presentation schedule) }\end{array}$ \\
\hline & To be continued.. & & & \\
\hline 4 & $\begin{array}{l}\text { The recap of the re- } \\
\text { search output is still } \\
\text { done manually. }\end{array}$ & $\begin{array}{l}\text { - It takes a long } \\
\text { time because it } \\
\text { still has to be }\end{array}$ & $\begin{array}{ll}\text { - } & \text { process cycle- } \\
\text { time reduction } \\
\text { - } & \text { error proofing } \\
\end{array}$ & \begin{tabular}{lr}
\multicolumn{3}{l}{ Develop an information } \\
system to $\begin{array}{r}\text { support } \\
\text { business }\end{array}$ & process
\end{tabular} \\
\hline
\end{tabular}




\begin{tabular}{|c|c|c|c|c|}
\hline & $\begin{array}{l}\text { (from the process } \\
\text { "checking content") }\end{array}$ & $\begin{array}{l}\text { downloaded } \\
\text { one by one from } \\
\text { email/google } \\
\text { drive. } \\
\text { prone to } \\
\text { missing data } \\
\text { because the } \\
\text { download } \\
\text { process still } \\
\text { clicks one by } \\
\text { one }\end{array}$ & - automation & $\begin{array}{l}\text { activities (can display } \\
\text { all data - all research } \\
\text { output from the final re- } \\
\text { port) }\end{array}$ \\
\hline 5 & $\begin{array}{l}\text { The final presenta- } \\
\text { tion assessment is } \\
\text { still written into the } \\
\text { paper-based assess- } \\
\text { ment form } \\
\text { (from the process } \\
\text { "write an assess- } \\
\text { ment to evaluation } \\
\text { form") }\end{array}$ & $\begin{array}{l}\text { - when this form } \\
\text { is collected } \\
\text { again (to } \\
\text { LPPM), it is } \\
\text { prone to lose } \\
\text { - the score can be } \\
\text { changed easily } \\
\text { by others }\end{array}$ & 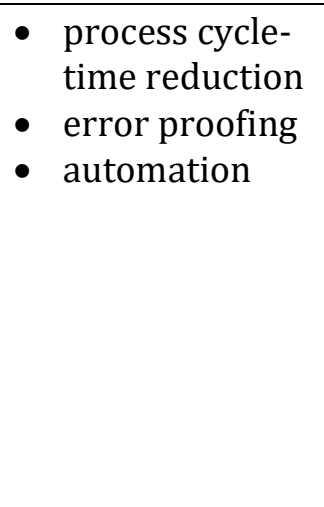 & $\begin{array}{l}\text { Develop an information } \\
\text { system to support } \\
\text { business } \\
\text { activities (has capabil- } \\
\text { ity to input reviewer } \\
\text { score to each proposer) }\end{array}$ \\
\hline 6 & $\begin{array}{l}\text { The recap process of } \\
\text { the final report as- } \\
\text { sessment that has } \\
\text { been received by } \\
\text { LPPM is still done } \\
\text { manually. } \\
\text { (from process "re- } \\
\text { cap the assess- } \\
\text { ment") }\end{array}$ & $\begin{array}{l}\text { - It takes a long } \\
\text { time because it } \\
\text { still has to be } \\
\text { read from the } \\
\text { assessment } \\
\text { form and writ- } \\
\text { ten into MS Ex- } \\
\text { cel or MS Word. } \\
\text { - prone to } \\
\text { missing data }\end{array}$ & 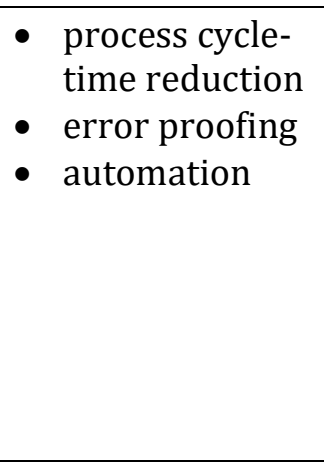 & $\begin{array}{l}\text { Develop an information } \\
\text { system to support } \\
\text { business } \\
\text { activities (can display } \\
\text { all data - all final report } \\
\text { assessment) }\end{array}$ \\
\hline
\end{tabular}

The improvement techniques and explanation of improvement techniques identified for all problems found in the business process of the final report's upload and presentation would be broken down into application requirements. The application would be web-based using the CI framework. The framework is used for its capability to provide consistent structure. This structure is essential so that the application that has been built can be easily maintained and upgraded. Because the framework has standard rules so that if the application wants to be upgraded (add some new features) and if the programmer changes (a case that is most likely to occur in the software development project), it will not take long for new programmers to learn the code structure from the existing application. He/She can start coding sooner, which later affected the overall project execution time. Because the application developed using a framework, it is best to display the system requirements (functional requirement) in a use case diagram. 


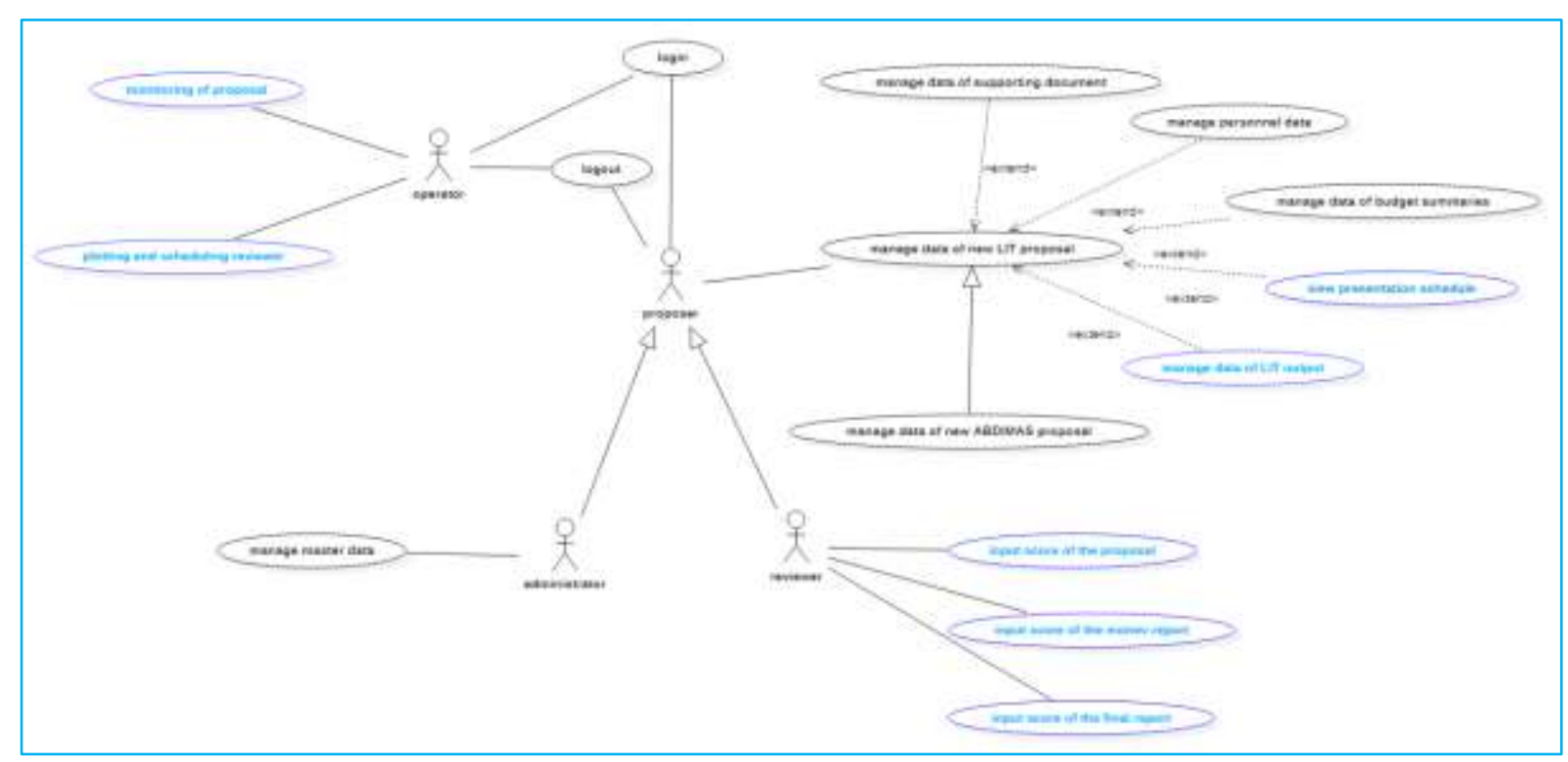

Figure 3. A proposed use case diagram

From the use case diagram shown in figure 3, the functional requirements of the application related to the upload and presentation of the final report process are indicated by the use case, which is written in blue font. The use case is the monitoring of proposal, plotting and scheduling reviewer, view presentation schedule, manage data of LIT output, input score of the proposal, input score of the monev report, and input score of the final report.

\section{Conclusion}

The results of the study can be concluded that:

1. Three business processes will be improved: business processes 1. proposal's upload and funded proposal's announcement; 2. LITDIMAS execution; 3. final report's upload and presentation.

2. Several problems exist in the business processes at LPPM. After identifying the problems and types of improvements needed using BPI tools, there is a recommendation to develop an information system.

3. The results of the recommendations are then mapped into a functional requirement of an application that results in 15 use cases, 7 of which are related to the upload process and presentation of the final report. The seven use cases are monitoring of proposal, plotting and scheduling reviewer, view presentation schedule, manage data of LIT output, input score of the proposal, input score of the monev report, and input score of the final report.

\section{Acknowledgment}

The author would like to thank UPN "Veteran" Jawa Timur who have funded this research and also LPPM UPN "Veteran" Jawa Timur who has been willing to be the research subject.

\section{References}

Bhakti, B. W., \& Herliani, S. (2018). Business process improvement pengelolaan dokumen (Studi Kasus : Unit PBJ DAOP 2, PT. Kereta Api). Konferensi Nasional Sistem Informasi, 217-254. doi: 10.1007/978-0-387-74526-8_13. 
Harrington, H. J. (1991a). Business process improvement: The breakthrough strategy for total quality, productivity, and competitiveness. McGraw-Hill Education. Available at: https://www.amazon.com/Business-Process-Improvement-BreakthroughCompetitiveness/dp/0070267685 (Accessed: 25 October 2020).

Harrington, H. J. (1991b). Improving Business Processes. The TQM Magazine, 3(1), 39-44. DOI: 10.1108/eb059514.

Helmi, A. T., Aknuranda, I., \& Saputra, M. C. (2018). Analisis dan pemodelan proses bisnis menggunakan Business Process Improvement (BPI) pada lembaga bimbingan belajar (Studi kasus: Lembaga bimbingan belajar prisma). Jurnal Pengembangan Teknologi Informasi dan Ilmu Komputer (J-PTIIK) Universitas Brawijaya, 2(10), 4184-4191

Weerakkody, V., Currie, W. L., \& Ekanayake, Y. (2003). Re-engineering business processes through application service providers: Challenges, issues and complexities. Business Process Management Journal, 9(6), 776-794. DOI: 10.1108/14637150310506693. 